\title{
EXPERIMENTAL INVESTIGATION OF THE ENERGY-POWER CHARACTERISTICS OF THE CLEANER OF THE ROOT CROP HEADS FROM THE HAULM
}

\author{
Volodymyr Bulgakov ${ }^{1}$, Semjons Ivanovs ${ }^{2}$, Francesco Santoro ${ }^{3}$, Alexandros Sotirios Anifantis ${ }^{3}$ \\ ${ }^{1}$ National University of Life and Environmental Sciences of Ukraine, Ukraine; ${ }^{2}$ Latvia University of \\ Life Sciences and Technologies, Latvia; ${ }^{3}$ University of Bari Aldo Moro, Italy \\ semjons@apollo.lv, francesco.santoro@uniba.it, alexandrossotirios.anifantis@uniba.it
}

\begin{abstract}
Sugar beet haulm is a valuable animal fodder or a raw material for biogas generation. The most important indicator of the work of the cleaners is their energy-power characteristics since they affect the amount of the operating costs and the economic performance, on the whole. The purpose of the experimental investigations was to determine the nature of the change in the torque moment and power on the drive of the vertical cleaner, tractive power, as well as the draft resistance of the root crop head cleaner. Experimental investigations were carried out under the field conditions. In order to study the draft resistance of the working tool, the tensometry method was used. Dependences of the change in the tractive power and the torque moment upon the speed of the movement of the experimental root head cleaner from the haulm residues have been determined. The rational modes of operation of the cleaner are: the forward speed of its movement, equal to $1.5 \mathrm{~m} \cdot \mathrm{s}^{-1}$, the angular speed of rotation of the cleaning tool must be within $60.0 \ldots 63.0 \mathrm{rad} \cdot \mathrm{s}^{-1}$. The completeness of cleaning the root crop heads from the haulm residues by the experimental cleaner is $95.9 \%$, the degree of throwing of the haulm and the plant residues beyond the row is $99.96 \%$.
\end{abstract}

Keywords: sugar beet, haulm, cleaner, energy, power, speed.

\section{Introduction}

Sugar beet cultivation is an important branch of agriculture in many countries [1-3]. Sugar beet harvesting is the most important and expensive technological operation. In order to achieve that the sugar-bearing root crops be stored for a certain period and did not contain unnecessary impurities during their processing, they must be separated from the haulm [4].

Sugar beet haulm is a valuable animal fodder or a raw material for biogas generation. Since significant cutting of the upper part of the root crop is not acceptable because of a considerable loss of the sugar-containing mass, it is usually carried out by cutting the haulm above the head of the root crop with the following additional cleaning of the remaining residues of the haulm using special machines or devices. After such an operation the roots are completely freed from unnecessary impurities and can be successfully used for storage and processing.

There are several types of designs for cleaners of the root crop heads from the residues of the haulm, and each of them has both advantages and disadvantages [5-6]. Good agrotechnical indicators under the conditions of Ukraine is a feature of the blade cleaner developed by us [7]. The most important indicator of the work of the cleaners is their energy-power characteristics, since they affect the amount of the operating costs and the economic performance, on the whole.

The work of the cleaners was investigated by many scientists [1;3;7], yet, the issue of finding less energy-consuming technical means still remains urgent.

In order to find rational design and technological parameters of the working tool of the cleaner of improved design, developed by us we conducted investigations to determine the nature of the change in the energy-power factors depending on two kinematic parameters: the forward speed of the cleaner movement and the angular speed of rotation of its cleaning tool. The purpose of the experimental investigations was to determine the nature of the change in the torque moment and power on the drive of the vertical cleaner, tractive power, as well as the draft resistance of the root crop head cleaner.

\section{Materials and methods}

To carry out the experiments, an aggregate was made of an MTZ- 80 wheeled aggregating tractor and an experimental field installation for cleaning the root crop heads by an experimental tool (Fig. 1) connected to a tensometric station (which, during the research, was moving side by side with the experimental installation) (Fig. 2).

The energy-power research was conducted at a constant position of the working blades relative to the surface of the soil. Based on the results of the technological research, the most efficient mode of 
operation of the cleaner was established, depending on the installation height of the cleaning blades. Therefore, we had selected the minimum installation height of the working blade, which was $0 \mathrm{~cm}$ above the soil surface.

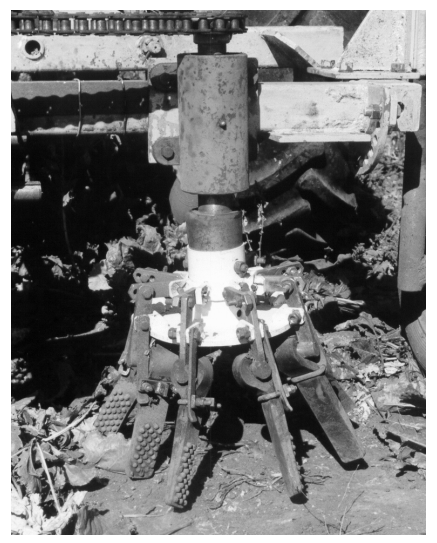

Fig. 1. Improved beet root head cleaner from haulm residues without extracting roots from the soil

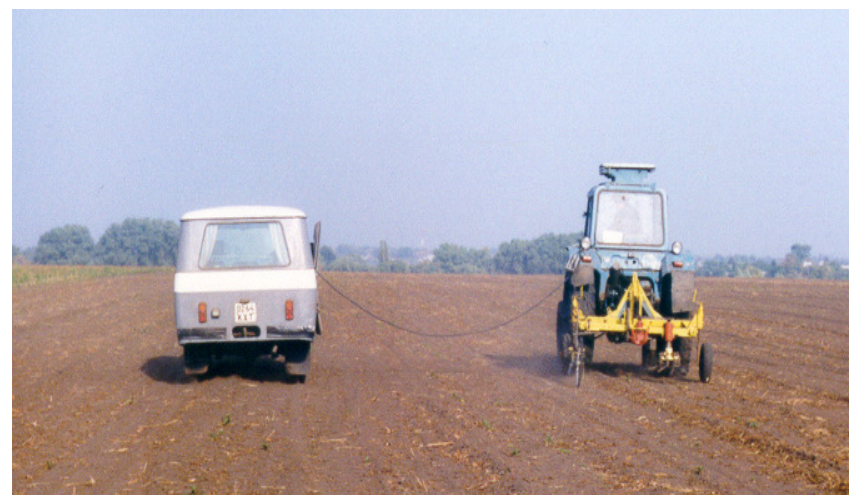

Fig. 2. General view of experimental installation under field conditions, connected to mobile tensometric station

The tensometric test was conducted at the Ukrainian Centre for Testing Technology (UkrCIT, Research Centre in Kiev region). The experimental research was carried out according to the standard methodology of energy estimation [8;9].

When conducting the research, two factors were changed: the speed of the movement and the angular speed of rotation of the cleaning tool. The tensometric tests were conducted in each mode of operation in five replications in accordance with the adopted methodology [10-14].

The main results of the technical and operational tests of the improved cleaner of sugar beet heads from haulm residues are presented in Table 1 . The conditions of the experimental field investigations are given in Table 2.

Table 1

Results of the technical and operational tests of the improved cleaner

\begin{tabular}{|l|c|c|}
\hline \multicolumn{1}{|c|}{ Indicators } & $\begin{array}{c}\text { According to the data of } \\
\text { technical specifications } \\
\text { (requirements) }\end{array}$ & $\begin{array}{c}\text { According to } \\
\text { the tests }\end{array}$ \\
\hline \multicolumn{1}{|c|}{ Efficiency, ha $\mathrm{h}:$ basic } & $1.78 \ldots . .2 .16$ & 1.64 \\
operational $^{-1}$ & $0.98 \ldots .30$ & 0.65 \\
\hline Working speed, $\mathrm{km} \cdot \mathrm{h}^{-1}$ & $6.5 \ldots 8.0$ & 6.9 \\
\hline Working width, $\mathrm{m}$ & - & 0.5 \\
\hline Number of the treated rows processed, pcs. & - & 1 \\
\hline Travelling speed, $\mathrm{km} \cdot \mathrm{h}^{-1}$ & - & up to 20 \\
\hline Number of the operating personnel & - & 1 \\
\hline Reliability coefficient of the technological process & Not less than 0.95 & 0.95 \\
\hline Outline dimensions in a working position, mm: & - & 720 \\
length \\
width \\
height & - & 1530 \\
\hline
\end{tabular}

A field experimental installation was created for experimental investigations of the energy characteristics of the developed cleaner, simulating the operation of a single cleaning tool, which was equipped with tensometric sensors. The scheme of the installation is shown in Fig. 3.

The tensometric (strain gauge) sensor (Fig. 4) records changes in the resistance moment on the power take-off shaft of the aggregating tractor, which, in turn, makes it possible to determine the power on the drive the investigated cleaning tool of the root head cleaner from the haulm residues 
without extracting the roots from the soil. By means of this sensor the speed of the rotational movement of the cleaning tool was also measured.

Table 2

Conditions of the experimental field investigations

\begin{tabular}{|c|c|c|}
\hline Indicator & $\begin{array}{l}\text { According to } \\
\text { the data of } \\
\text { technical } \\
\text { specifications }\end{array}$ & $\begin{array}{l}\text { According to the } \\
\text { tests }\end{array}$ \\
\hline $\begin{array}{l}\text { Characteristics of sugar beet: } \\
\text { Deviation of the root crops from the theoretical axis } \\
\text { of the row, \% } \\
\qquad \begin{array}{ll}0 \mathrm{~mm} \\
\pm 10 \mathrm{~mm} \\
\pm 20 \mathrm{~mm} \\
\pm 30 \mathrm{~mm} \\
\pm 40 \mathrm{~mm} \text { and more }\end{array}\end{array}$ & $\begin{array}{l}- \\
- \\
- \\
-\end{array}$ & $\begin{array}{c}7.2 \\
15.8 \\
20.9 \\
30.9 \\
25.2\end{array}$ \\
\hline $\begin{array}{l}\text { Spacing of the root crop heads relative to the soil } \\
\text { surface level, } \% \\
\text { from } 0 \mathrm{~mm} \text { to } 20 \mathrm{~mm} \\
\text { from }+20 \mathrm{~mm} \text { to }+40 \mathrm{~mm} \\
\text { from }+40 \mathrm{~mm} \text { to }+60 \mathrm{~mm} \\
\text { more than }+60 \mathrm{~mm} \text { to }+80 \mathrm{~mm} \\
\text { more than }+80 \mathrm{~mm}\end{array}$ & $\begin{array}{l}- \\
- \\
- \\
- \\
- \\
-\end{array}$ & $\begin{array}{c}0.0 \\
36.4 \\
22.7 \\
19.3 \\
11.4 \\
10.2\end{array}$ \\
\hline $\begin{array}{l}\text { Main inter-row spacing: } \\
\text { medium, cm } \\
\text { mean square deviation, } \pm \mathrm{cm}\end{array}$ & $\begin{array}{r}- \\
\pm 0.3 \\
\end{array}$ & $\begin{array}{c}44.5 \\
1.0\end{array}$ \\
\hline $\begin{array}{l}\text { Plant spacing: } \\
\text { average distance between the roots, } \mathrm{cm}\end{array}$ & - & 26.8 \\
\hline Plant density, thousand pieces $\cdot \mathrm{ha}^{-1}$ & - & 82.9 \\
\hline Biological yield of the root crops, $\mathrm{t} \cdot \mathrm{ha}^{-1}$ & 70.0 & 53.3 \\
\hline Biological yield of the haulm, $\mathrm{t} \cdot \mathrm{ha}^{-1}$ & 20.00 & 13.3 \\
\hline $\begin{array}{l}\text { Type of soil and name by the mechanical } \\
\text { composition }\end{array}$ & - & $\begin{array}{l}\begin{array}{c}\text { Low-humus } \\
\text { chernozem }\end{array} \\
\end{array}$ \\
\hline Relief & up to $7^{\circ}$ & Flat \\
\hline $\begin{array}{l}\text { Soil moisture in a layer, } \% \\
\qquad \begin{array}{l}0-10 \mathrm{~cm} \\
10-20 \mathrm{~cm} \\
20-30 \mathrm{~cm}\end{array}\end{array}$ & $\begin{aligned} 20.0 & : 23.0 \\
& - \\
& -\end{aligned}$ & $\begin{array}{l}22.5 \\
22.1 \\
22.6\end{array}$ \\
\hline $\begin{array}{l}\text { Soil hardness in a layer, MPa: } 0-10 \mathrm{~cm} \\
\qquad 10-20 \mathrm{~cm}\end{array}$ & - & $\begin{array}{l}1.1 \\
2.0\end{array}$ \\
\hline $\begin{array}{l}\text { Weediness of the field: pieces } / \mathrm{m}^{2} \text { (up to } 100 \mathrm{~cm} \\
\text { high) }\end{array}$ & $\begin{array}{l}\text { Not more than } \\
5.0\end{array}$ & 4.0 \\
\hline Precursor and pre-treatment of soil & - & $\begin{array}{l}\text { Winter wheat, } \\
\text { inter-row } \\
\text { loosening }\end{array}$ \\
\hline
\end{tabular}

The installation was also equipped with a measuring wheel (Fig. 5), which made it possible to measure with high accuracy the forward speed of the movement of the experimental installation with an installed root head cleaner along the axis of the row of the sugar beet plantations. Tensometric sensors were also stuck on the rear semi-axle of the aggregating tractor, which made it possible to measure the torque moment on its semi-axles during the experimental investigations, and then to calculate the draft resistance of the improved root crop head cleaner from the haulm residue, using a computer program. 


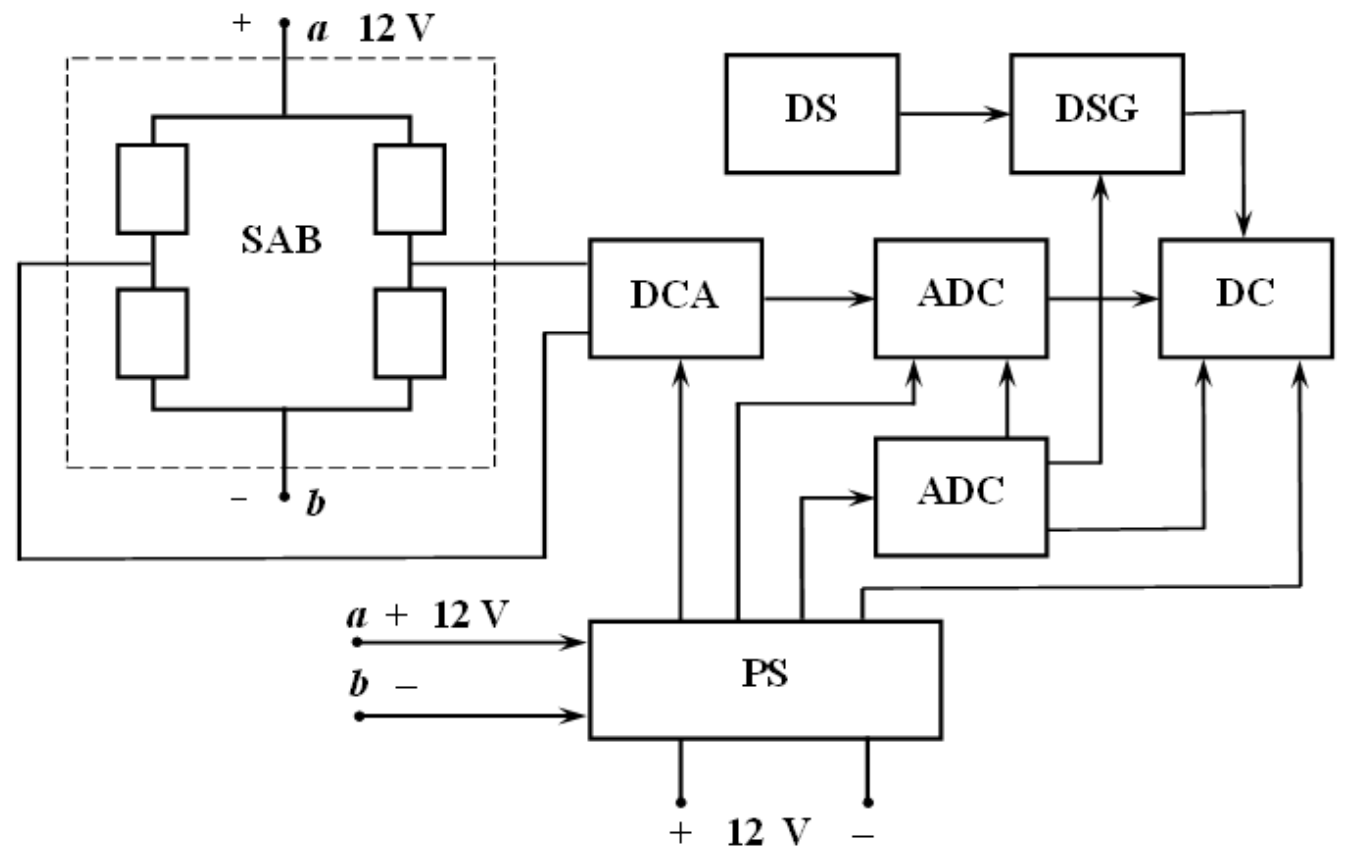

Fig. 3. Block diagram of measuring equipment: $\mathrm{SAB}$ - discrete sensor; DSG - discrete signal generator; CB - control board; DC - display console; PS - power supply

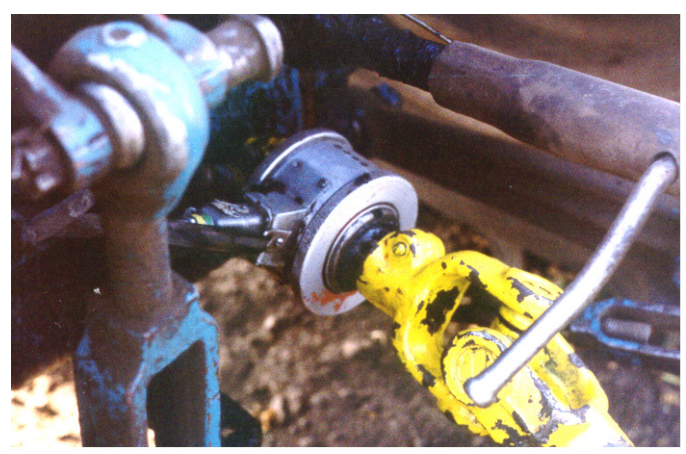

Fig. 4. Tensometric sensor of drive of root crop head cleaner

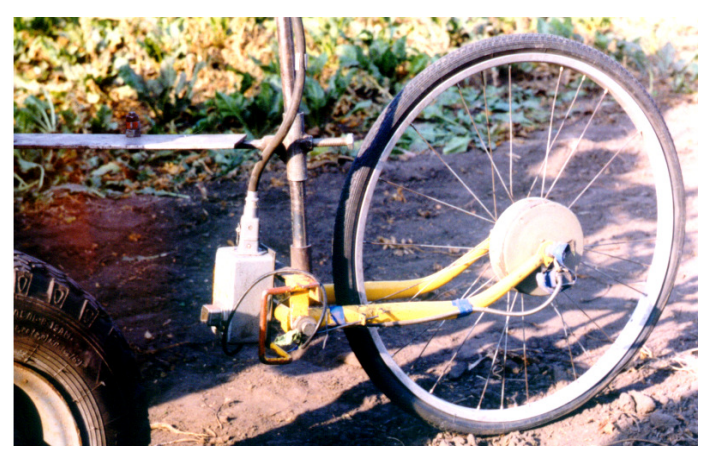

Fig. 5. Tensometric sensor of drive of root crop head cleaner

The experiments were carried out at three speeds of the movement of the aggregating tractor: 0.8 , 1.3 and $1.9 \mathrm{~m} \cdot \mathrm{s}^{-1}$. These speeds of the aggregating tractor determined the speed ranges for conducting the experimental field investigations, since the data from the sensor readings of the track measuring wheel were transmitted to the computer, which determined the exact value of the forward speed of the experimental installation. At each speed of the movement, by replacing the drive sprocket of the cleaner tool of the cleaning device, its rotation frequency was changed three times, and it corresponded to the following values: 448, 540 and 734 revolutions per minute. The exact value of the rotation frequency of the cleaning tool for each drive sprocket was thoroughly tested under laboratory conditions, using a tachometer. The experimental studies were conducted at a constant position of the cleaning shaft with flexible blades in a vertical plane, i.e. at a constant height of its installation above the surface of the soil. All the experiments were performed in triplicate according to the developed methodology.

\section{Results and discussion}

By means of the results of the tensometric tests and their processing, using statistical methods, graphical dependencies were built on the PC, presented in Figs. 6-9, characterising the change in the energy indicators of the work of the improved cleaner depending on the change in its forward speed. Analysis of the dependences, presented in Fig. 6, shows that, with increasing the forward speed of the 
cleaner from $0.75 \mathrm{~m} \cdot \mathrm{s}^{-1}$ to $1.1 \mathrm{~m} \cdot \mathrm{s}^{-1}$, the torque moment gradually decreases from $6.0 \mathrm{~N} \cdot \mathrm{m}$ to $4.25 \mathrm{~N} \cdot \mathrm{m}$ (Curve 1), and from $7.5 \mathrm{~N} \cdot \mathrm{m}$ to $5.95 \mathrm{~N} \cdot \mathrm{m}$ (Curve 2), the corresponding angular speeds of rotation of the cleaning shaft being $78.6 \mathrm{rad} \cdot \mathrm{s}^{-1}$ and $56.5 \mathrm{rad} \cdot \mathrm{s}^{-1}$. With a further increase in the forward speed up to $2.0 \mathrm{~m} \cdot \mathrm{s}^{-1}$, a significant increase in the torque moment is observed, respectively, up to $19.0 \mathrm{~N} \cdot \mathrm{m}$ with an angular speed of rotation of the cleaning tool, equal to $78.6 \mathrm{rad} \cdot \mathrm{s}^{-1}$, and up to $15.5 \mathrm{~N} \cdot \mathrm{m}$ with an angular speed, equal to $56.5 \mathrm{rad} \cdot \mathrm{s}^{-1}$. At the angular speed of rotation of the cleaning shaft, equal to $46.9 \mathrm{rad} \cdot \mathrm{s}^{-1}$, the torque increases throughout the entire range of changes in the forward speed of movement from $3.5 \mathrm{~N} \cdot \mathrm{m}$ to $10.5 \mathrm{~N} \cdot \mathrm{m}$. This is a witness of a fairly stable energy process, observed during the cleaning of the sugar beet roots from the haulm residues without extracting the roots from the soil.

There is a similar increase in the resistance force to the movement of the improved cleaner (Fig. 7), yet, the increase in the resistance force is insignificant - from 0.047 to $0.06 \mathrm{kN}$ (Curve 1), and from 0.063 to $0.073 \mathrm{kN}$ (Curve 2), respectively, at $\omega=78.6 \mathrm{rad} \cdot \mathrm{s}^{-1}$, and $\omega=56.5 \mathrm{rad} \cdot \mathrm{s}^{-1}$.

The dependence of power on the drive of the cleaning tool, which was recorded by the sensor, installed on the power take-off shaft of the aggregating tractor, upon the speed of the cleaner, presented in Fig. 8, shows that the maximum value of power does not exceed $1.5 \mathrm{~kW}$.

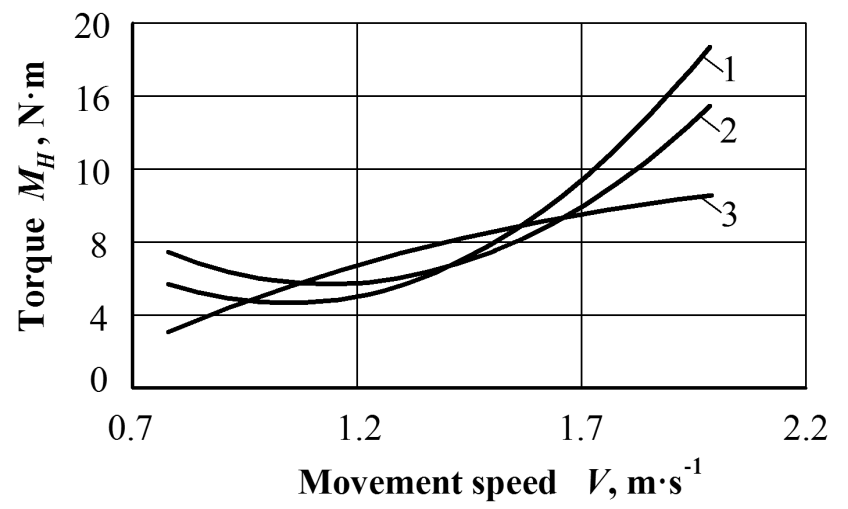

Fig. 6. Dependence of torque moment upon speed of movement of cleaner:

$$
1-\omega=78.6 \mathrm{rad} \cdot \mathrm{s}^{-1} ; 2-\omega=56.5 \mathrm{rad} \cdot \mathrm{s}^{-1} ; 3-\omega=46.9 \mathrm{rad} \cdot \mathrm{s}^{-1}
$$

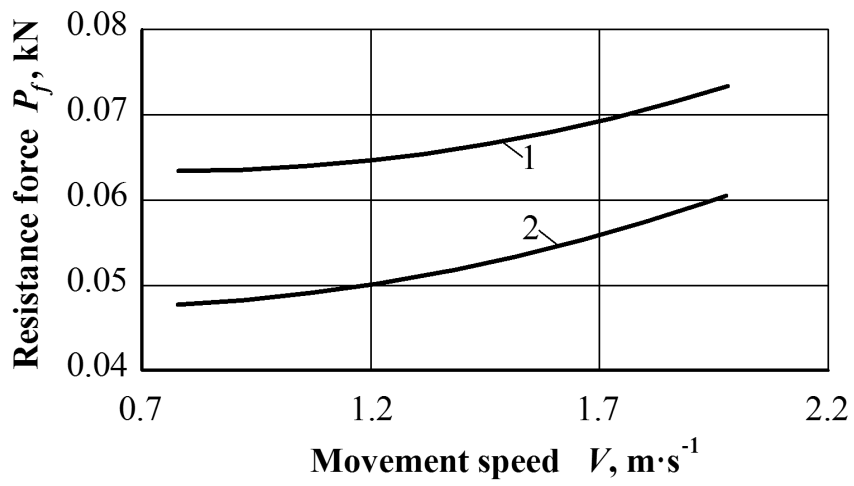

Fig. 7. Dependence of resistance force to movement of cleaner upon speed of its forward movement: $1-\omega=78.6 \cdot \mathrm{rad} \cdot \mathrm{s}^{-1} ; 2-\omega=56.5 \mathrm{rad} \cdot \mathrm{s}^{-1}$

The change in the tractive force, depending on the speed of the forward movement, occurs almost according to a linear law (Fig. 9), the decrease in the angular velocity of rotation of the pre-cleaning tool in the range 78.6...56.5 rad. $\mathrm{s}^{-1}$ not leading to significant changes in the tractive force (Curves 1 , 2). After the analysis of the data of the tensometric tests one can draw a conclusion that rational modes of operation of the root head cleaner from the haulm residues are: the forward speed of its movement should be equal to $1.5 \mathrm{~m} \cdot \mathrm{s}^{-1}$, the angular speed of rotation of the cleaning tool should be within the limits 60.0...63.0 rad $\cdot \mathrm{s}^{-1}$. We have also conducted a comparative assessment of the efficiency of using energy by the root head cleaner from the haulm residues, developed by us, with similar indicators of commercially available trailed root head cleaners from the haulm residues of the OGD-6 and OGD-6 
B brands, the results of which are presented in Table. 3. Besides, the indicators of the energy efficiency of the root head cleaner from the haulm residues, developed by us, were averaged considering its sextuple application.

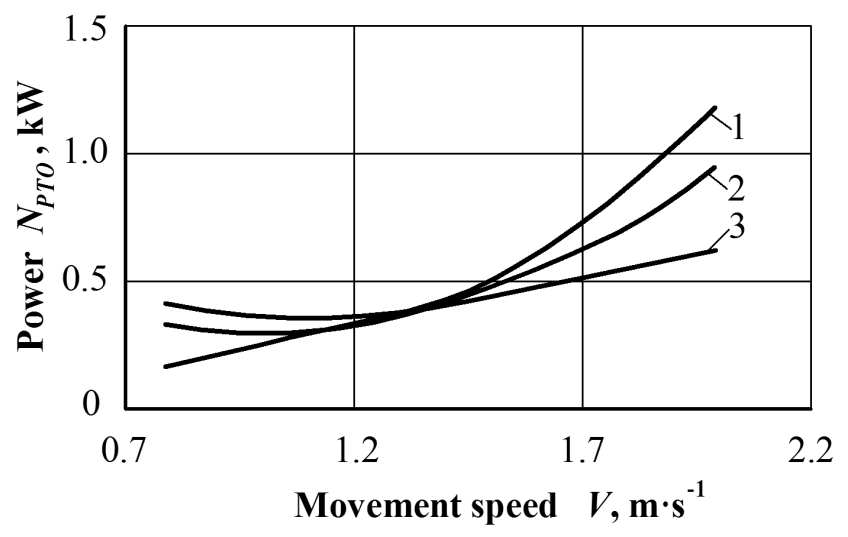

Fig. 8. Dependence of power on PTO shaft upon speed of movement of cleaner: $1-\omega=78.6 \mathrm{rad} \cdot \mathrm{s}^{-1} ; 2-\omega=56.5 \mathrm{rad} \cdot \mathrm{s}^{-1} ; 3-\omega=46.9 \mathrm{rad} \cdot \mathrm{s}^{-1}$

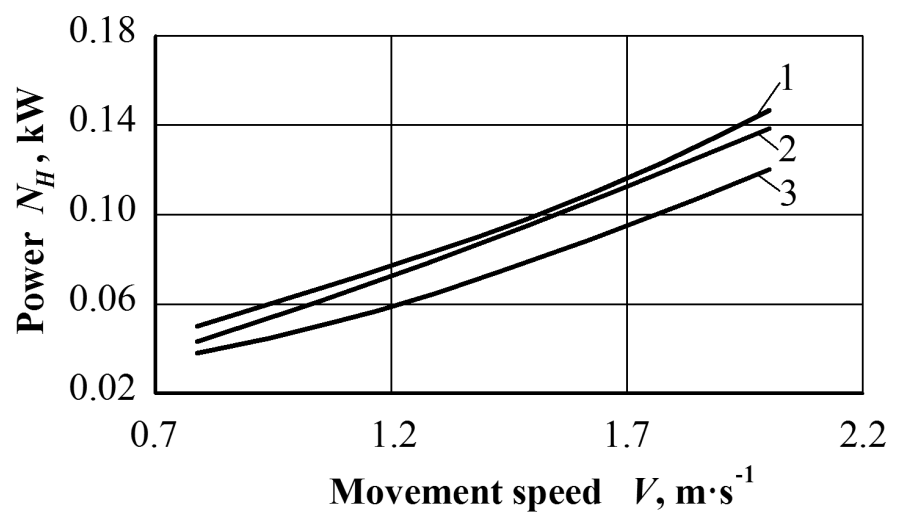

Fig.9. Dependence of tractive force upon forward speed of movement of cleaner:

$$
1-\omega=78.6 \mathrm{rad} \cdot \mathrm{s}^{-1} ; 2-\omega=56.5 \mathrm{rad} \cdot \mathrm{s}^{-1} ; 3-\omega=46.9 \mathrm{rad} \cdot \mathrm{s}^{-1}
$$

As it is evident from the data of this comparative assessment, the draft resistance of the cleaner, developed by us, is 3.5...4.0 times less than that of the basic cleaners, the tractive power is also less approximately 3.0...4.0 times, the torque moment is $2.5 \ldots 3.5$ times, and the power on the drive of the cleaner is almost 3.5...4.0 times. Alongside with the energy assessment, agrotechnical tests of the developed cleaner with justified structural and kinematic parameters were carried out. The indicators of the quality of work were determined according to the developed methodology. The installation height of the blade above the soil surface is $0.0 \mathrm{~cm}$, the angular speed of rotation of the vertical cleaning shaft is $76.8 \mathrm{rad} \cdot \mathrm{s}^{-1}$, the forward speed of the aggregate is $1.8 \mathrm{~m} \cdot \mathrm{s}^{-1}$, the length of the working blade is $20 \mathrm{~cm}$, and its width is $5.0 \mathrm{~cm}$.

Table 3

Comparative assessment of the energy efficiency indicators of the root crop head cleaners from the haulm residues of various types

\begin{tabular}{|l|c|c|c|}
\hline \multicolumn{1}{|c|}{ Indicator } & OGD-6B & OGD-6 & $\begin{array}{c}\text { The experimental } \\
\text { cleaner }\end{array}$ \\
\hline Speed of the movement, $\mathrm{m} \cdot \mathrm{s}^{-1}$ & 1.82 & 1.81 & 1.96 \\
\hline Draft resistance, $\mathrm{kN}$ & 1.40 & 1.70 & 0.40 \\
\hline Tractive power, $\mathrm{kW}$ & 2.50 & 3.10. & 0.80 \\
\hline Torque moment on the PTO shaft, $\mathrm{N} \cdot \mathrm{m}$ & 209.40 & 280.00 & 81.20 \\
\hline Power on the power take-of, $\mathrm{kW}$ & 13.50 & 18.00 & 4.80 \\
\hline
\end{tabular}


As a result of the agrotechnical research, it was also established that, when using the experimental cleaner, the completeness of cleaning the root crop heads from the haulm residues is $95.9 \%$, the degree of throwing of the haulm and the plant residues beyond the row is $99.96 \%$, which not only satisfies the agrotechnical requirements for cleaning the sugar beet heads from the plant residues, but also significantly excels them.

\section{Conclusions}

1. Dependences of the change in the tractive power and the torque moment upon the speed of the movement of the experimental root head cleaner from the haulm residues have been determined.

2. The rational modes of operation of the cleaner are: the forward speed of its movement, equal to $1.5 \mathrm{~m} \cdot \mathrm{s}^{-1}$, the angular speed of rotation of the cleaning tool must be within $60.0 \ldots 63.0 \mathrm{rad} \cdot \mathrm{s}^{-1}$.

3. The completeness of cleaning the root crop heads from the haulm residues by the experimental cleaner is $95.9 \%$, the degree of throwing of the haulm and the plant residues beyond the row is $99.96 \%$.

\section{References}

[1] Vilde A. Development of technologies and machinery for production of sugar beet in Latvia. Proceedings of the conference „Safe and economocal agricultural technologies” (Priekulii, Latvia), 2002, pp. 62-66.

[2] Merkes R. 50 Jahre Prodaktionstechnik im Zuckerr. Benbau in Deutchland. Zucker., No 4, 2001, pp. 214-217.

[3] Погорелый Л.В., Татьянко Н.В., Свеклоуборочные машины (Beet Harvesting Machines). Киев, 2004, 232 p. (In Ukrainian).

[4] Максаков В. Ботва, жом и мелисы при кормлении животных (The haulm, pulp and melissa when feeding animals), Киев, 1993, 145 p. (In Russian).

[5] Bulgakov V., Ivanovs S., Ruzhylo Z., Golovach I. Theoretical investigations in cleaning sugar beet heads from remnants of leaves by cleaning blade. Engineering for Rural Development, Proceedings, Vol. 15, 2016, pp.1090-1097.

[6] Хелемендик Н.M. Направления и методы разработки новых рабочих органов сельскохозяйственных машин. Монография (Directions and Methods for the Development of New Operating Tools of Agricultural Machines. A Monograph), Киев: Аграрная наука, 2001, 280 p. (In Ukrainian).

[7] Bulgakov V., Ivanovs S., Adamchuk V., Boris A. Mathematical model for determination of losses of sugar bearing-mass when sugar beet tops are removed. Engineering for Rural Development, Proceedings, Vol. 14, 2015, pp. 41-45.

[8] ГОСТ 20915-11. Техника сельскохозяйственная. Методы определения условий испытаний. (Agricultural machinery. Methods for the determination of the test conditions), Москва, 2011, 34 p.

[9] ГОСТ 52777-2007. Техника сельскохозяйственная. Методы энергетической оценки (Agricultural machinery. Methods for epy energy assessment), Москва, 2007, 18 p.

[10] Smith D.W., Sims B.G., O'Neill D.H. Testing and evalution of agricultural machinery and equioment. FAO Agricultural services bulletin, No 110, 1994, 288 p.

[11]Маленко В.И. Методы экспериментального определения силовых характеристик рабочих органов почвообрабатывающих орудий (Methods of experimental determination of the power characteristics of the operating tools of the soil tillage implements), Новосибирск, 1992, $106 \mathrm{p}$.

[12] Bulgakov V., Zaryshnyak A., Beloev H., Ivanovs S. Investigation of amplitude-frequency characteristics of disturbing and control impacts of asymmetric swath header machine-and-tractor aggregate. Engineering for rural development, proceedings, Vol. 17, 2018, pp. 221-226.

[13]Высоцкий A.A. Динамометрирование сельскохозяйственных машин (Dynamometry of agricultural machines), Москва, 1998, 290 p.

[14] Silva, R.P., Rolim, M.M., Gomes, I.F., Pedrosa, E.M.R., Tavares, U.E., Santos, A.N. Numerical modeling of soil compaction in a sugarcane crop using the finite element. Soil and Tillage Research, Vol. 181, 2018, pp. 1-10. 